\title{
Evaluating Business Success Through Social Media Strategies Using AHP
}

\author{
Mervegül Toğlukdemir, Elif Tuygan, Hasan Efe Yeşil \\ Management of Technology, \\ Istanbul Technical University \\ Maçka Istanbul 34367, Turkey \\ Email: \{toglukdemirm, tuygan15, yesil15\}@itu.edu.tr
}

\author{
Gülgün Kayakutlu \\ Industrial Engineering Department, \\ Istanbul Technical University \\ Maçka Istanbul 34367, Turkey \\ Email: kayakutlu@itu.edu.tr
}

\begin{abstract}
Social Media has become indispensable for market penetration. It is a beneficial communication platform for understanding the customer focus. Effective use of this media for image creation, customer access, knowledge accumulation and trend analysis, creates competitive advantages. This research is designed to analyze social media strategies of global enterprises and evaluate the value of social media usage. Analytical Hierarchy Process (AHP) is used to model the performance decisions. The model is constructed based on the major evaluation criteria used by the global companies. AHP model expresses cause and effect relationships between companies and social media effects. Cases will be applied for Coca Cola, Turkish Airlines and Starbucks. Enterprise awareness and success of different evaluation criteria are benchmarked.
\end{abstract}

Index Terms-Analytic Hierarchy Process, Social Networks, Strategic Planning and Management

\section{INTRODUCTION}

$\mathrm{T}$ HE Internet has been evolved from a basic tool of communications into an interactive market of products, services to global community and worldwide business transactions. Many enterprises attempt to embrace the digital revolution and using internet is now a necessity for the enterprises. As a result of the increased use of the Internet, using social media also became competitive advantage for the growing companies, they attempt to differentiate their products and services from competitors.

The past decade development and change of the usage of the Internet, it is difficult to differentiate in the global community only with one-way communications from seller to buyer thus, companies aim to interact more with their customers as well as to allow their customers to interact more with them (Winer, 2009). Since social media content has become indispensable to millions of users, it becomes wide source of big data and allows companies to reach more people at a lower costs. Social media is a great opportunity to communicate with customers for the companies, it provides to collect a big data of the users through their expectations, experiences, ideas and reactions for the product. Another benefit of social media is the quick interaction. The ability to receive quick reaction, in terms of ensuring a positive brand image is of great importance. It may take a second customers to respond a message posted on social platforms thus it helps companies to measure the pulse of the customers' ideas based on their positive or negative comments.

The objective of this study is to analyze the value of social media and social web data for businesses to differentiate in the global competition, and propose a theoretical explanation by analyzing social media strategies of the Turkish Airlines, Coca Cola and Starbucks which are global companies. This study involves main titles; firstly, importance of the social media analyzes for the enterprises' success across the globe will be studied. Secondly, Analytic Hierarchy Process method will be explained in steps, which contains explanations and the description of formulations. Thirdly, to analyze companies' awareness on social media, the main goal, criteria and alternatives for the AHP method will be obtained and explained in detail. Then, the sample using AHP method from the literature will be examined. Finally, results will be evaluated and by using AHP method an expressive cause and effect relationships between companies and social media effects are established.

\section{Literature Review: Knowledge Management In Social Media Strategies}

The widespread use of the social media in recent years it has become an important marketing strategy for the companies to meet directly with the customer in easiest, cheapest and fastest way. Social media helps reshape business models through opinions and emotions owing to fact that it opens up many possibilities to study human interaction and collective behavior. Many companies today are using social media to develop targeted campaigns that reach specific segments and engage their customers.

The past decade development and change of the Internet, numerous social networking sites have been drawing people together and creating new forms of communication. There are various social media forms; people write encyclopedia articles, online marketplaces recommend products via user shopping interactions; and community movements benefit from new forms of collective actions (Tang, Liu, 2010).

According to Feng and Qjan, "Facebook has about one billion users and there are about 3 million photos uploaded by users each day" (2013). LinkedIn is another example, the user can create a professional profile, establish connections to other users, and exchange messages, follow the current news. Tanbeer, Leung and Cameron stated that "social entity is connected to another entity as his or her next-of-kin, friend, collaborator, co-author, classmate, co- worker, team member, and/or business partner" (2014). 


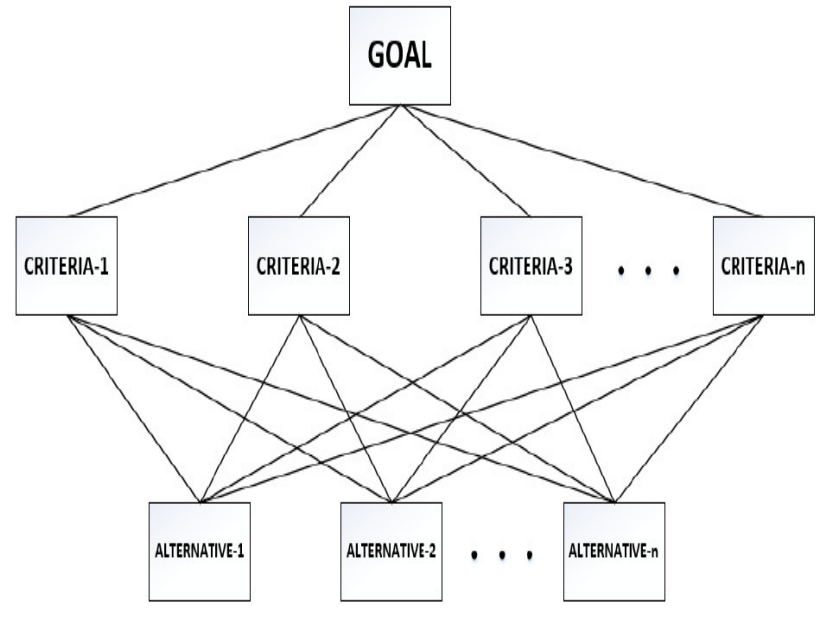

Fig 1. Hierarchical Structure of AHP

Mentioned connection might be used as a power to reach more customer. Thus the social media Websites are the ideal platforms to facilitate the products recommendation and market popularity. Social media has become wide source of big data for the companies. It is significant to analyze the social media entirely for the companies considering their target. Analyzing Social Media includes theories and methodologies from different disciplines such as computer science, data mining, machine learning, social network analysis, sociology, ethnography, statistics, optimization, and mathematics (Zafarani, Abbasi and Huan, 2014). The correct analysis of social media data is considered as the very important step of a successful marketing strategy for the growing companies.

\section{Methodology Implemented: Analytic Hierarchy Process (AHP)}

People make their decisions in two ways; the first is heuristic approach that develops very fast and is usually not objective. The second is the logical analysis that requires an analytical method. Analytic Hierarchy Process is a quantitative decision-making method according to multiple criteria and alternatives based on mathematics and psychology. Saaty stated that "a hierarchy is a representation of complex problem in a multilevel structure whose first level is the goal followed successively by levels of factors, criteria, sub-criteria, and so on down to bottom level of alternatives" (2006).

AHP lead the way that yield best in order to reach the goal/solve the decision problem instead of stating correct decision. The decision problem dissociated into hierarchy that contain criteria and alternatives. The hierarchy shows causeeffect relations in linear chain. After identifying the problem or stating the goal, hierarchy is created considering main decision point, middle level criteria and the lowest level of the possible alternatives (Figure 1).

Once hierarchy is built, the decision maker evaluate its elements (criteria and alternatives) by comparing their impact/effect on an element in the hierarchy between each other. In comparison, concrete data, judgments, expert opinions or survey results etc. are used as resource by decision maker in order to determine the degree of importance between elements. The importance scale table is used for comparison (Table 1).

TABLE I.

Importance OF ScAle AHP

\begin{tabular}{|l|c|}
\hline \multicolumn{1}{|c|}{ Definition } & Degree of importance \\
\hline Equally important & 1 \\
\hline Moderately important & 3 \\
\hline Strongly important & 5 \\
\hline Very strongly important & 7 \\
\hline Extremely important & 9 \\
\hline $\begin{array}{l}\text { Intermediate values between two } \\
\text { adjacent judgments }\end{array}$ & $2,4,6,8$ \\
\hline
\end{tabular}

The importance or numerical weights (according to degree of importance) are obtained for each criteria and alternative in the hierarchy so that benchmarking is made in a consistent and rational way. Finally, according degree of importance numerical importance are calculated for each decision alternatives. This evaluation shows ability of alternatives to achieve the goal (attracting customer through social media).

In this study, computer software "Super Decisions" is used for calculations so mathematical formulas not stated in detail. Steps are required to be resolved in a decision-making problem with AHP are summarized as follows:

Step 1. Model the problem as a hierarchy containing the decision goal, the alternatives for reaching it, and the criteria for evaluating the alternatives.

Step 2. Establish priorities among the elements of the hierarchy by making a series of judgments based on pairwise comparisons of the elements. For example, when comparing potential purchases of commercial real estate, the investors might say that location is five times important than price and price is three times important than timing.

Step 3. Synthesize these judgments to yield a set of overall importance for the hierarchy. This would combine the investors' judgments about location, price and timing for properties A, B, C, and D into overall importance for each property.

Step 4. Check the consistency of the judgments.

Step 5. Come to a final decision based on the results of this process. (Saaty, 2008)

\section{Creating the Model}

\section{A. Determining the Goal of AHP Model}

In this study, "attracting customers through social media" is chosen as main goal for the hierarchy tree.

\section{B. Determining the Criteria of AHP Model}

The criteria will be studied on three of the most common social media tools which provides companies have the opportunity to reach very large data, are chosen; LinkedIn as 


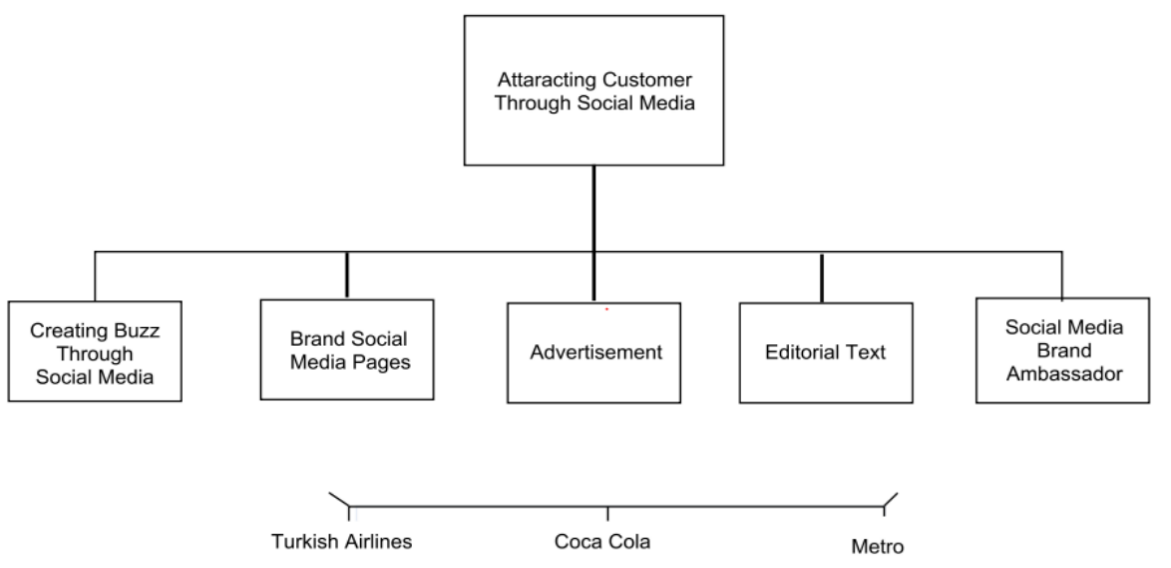

Fig 2. AHP decision tree

professional social media tool since people share their business information, resume and career histories in, Twitter as entertainment and news social media tool since people share their thoughts worldwide and Facebook as associational social media tool since it has become one of the most widely used tools for advertisement and reaching users (Drury, 2008). Determined criteria are as follows:

Brand Social Media Pages: Through social networking profiles of a brand it is possible to analyze demographics of the customers/followers, their interests, location information in order to devise new strategies.

Social Media Advertising: The most commonly adopted approach to the social media advertisement is to advertise on the social networks with the consultation of businesses, which have proved themselves with their experience on social media.

Editorial Text on Social Media: This kind of a communication will not force the customer to buy goods. It is built on arousing curiosity, giving information and offering benefits to the customer.

Social Media Brand Ambassador: Companies find the social network celebrity that suits the brand. It is of course a must for this person to have enough followers on certain networks too.

Creating Buzz Through Social Media: According to this marketing trend, volunteers found by a company convey their experience with a specific product to the people who they encounter with at any time.

\section{Determining the Alternatives of AHP Model}

The alternatives: three global companies are determined as follows:

Turkish Airlines: Recognized as a global brand Turkish Airlines (Turk Hava Yolları / THY) took 3rd place as one of the most active brands in social media. THY actively use social media, broadcasts in Turkish and English languages. In addition to Company has 8 million over Facebook fans and has over 1 million followers on Twitter. The profile of the brand via Facebook Turkish Airlines Euro league, Barcelona and Manchester United sponsorship or related information, campaigns and current developments can be followed.

Coca Cola: Coca Cola is actively using the Facebook and Twitter both products and campaigns. According to Social Media Principles of the social media strategy of the company is that more than 150,000 associates in more than 200 countries to join conversations take place online about Coca-Cola, represent the company, and share the optimistic and positive spirits of the brand (Coca Cola Company, 2013). Coca-Cola among the best in the world with more than 97 million members on Facebook and it has more than 170 thousand fans from Turkey. A. On Twitter also it has 93 thousand followers.

Starbucks: Starbucks has 640 thousand over Facebook fans and has over 74 thousand followers on Twitter.

After decision of the main goal, criteria, and alternatives; Hierarchical Structure of AHP is created. (Figure 2)

\section{Application}

\section{A. Applying the Model on a Software}

AHP/ANP software that is called Super Decisions is used in the scope of this study. Clusters and nodes are created according to Figure 2 and illustrated in Figure 3.

According to importance level that are shown in Table 1. the nodes of criteria cluster; the nodes of criteria cluster and the nodes of alternative cluster; the nodes of alternative cluster and nodes of criteria cluster are compared two by two (several importance table are shown in Appendix 1).

Companies are utilized according to usage of such social media tools:

- Professional social media tools (LinkedIn),

- Entertainment, new social media tool (Twitter),

- Associational social media tool (Facebook)

Some examples;

With respect to Coca-Cola, creating buzz trough social media is moderately more important than brand social me- 


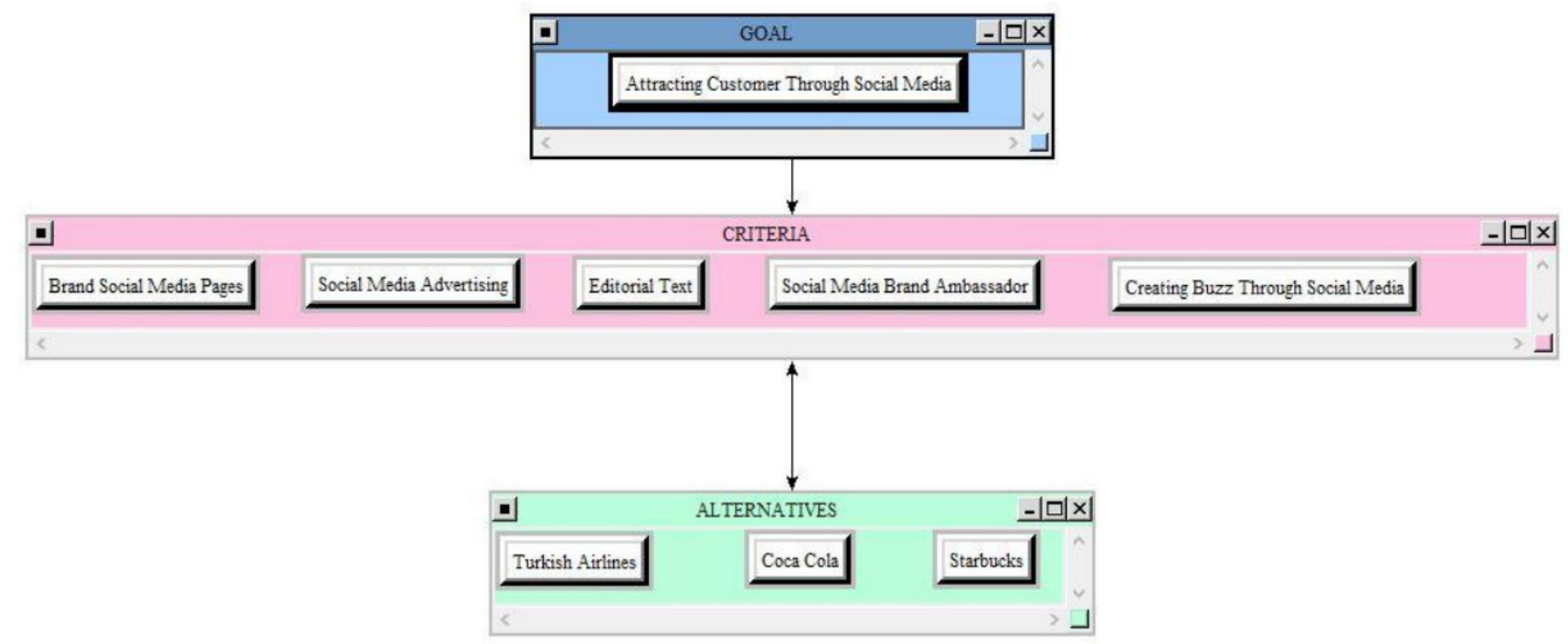

Fig 3. AHP decision tree

dia; brand social media is strongly more important than editorial text and so on.

\section{B. Results and Discussions}

According to our observations and reviews with alternative companies in Turkey, the importance of the each social media tools is different for each company (approximate values are shown in Table 2).

Software reports are shown in Table 2 and Table 3, accordingly.
As it seems in Table 3, in the scope of social media (LinkedIn, Facebook, Twitter), in order to attract the customer Coca Cola is using social media tool more effective than Turkish Airlines; Turkish Airlines is using social media tool more effective than Starbucks.

\section{Conclusion And Recommendations}

Social media is important trend, the company has become an important marketing opportunity to meet directly with the customer. Social media allows businesses to communicate

TABLE II

Main structure in Super Decision Report

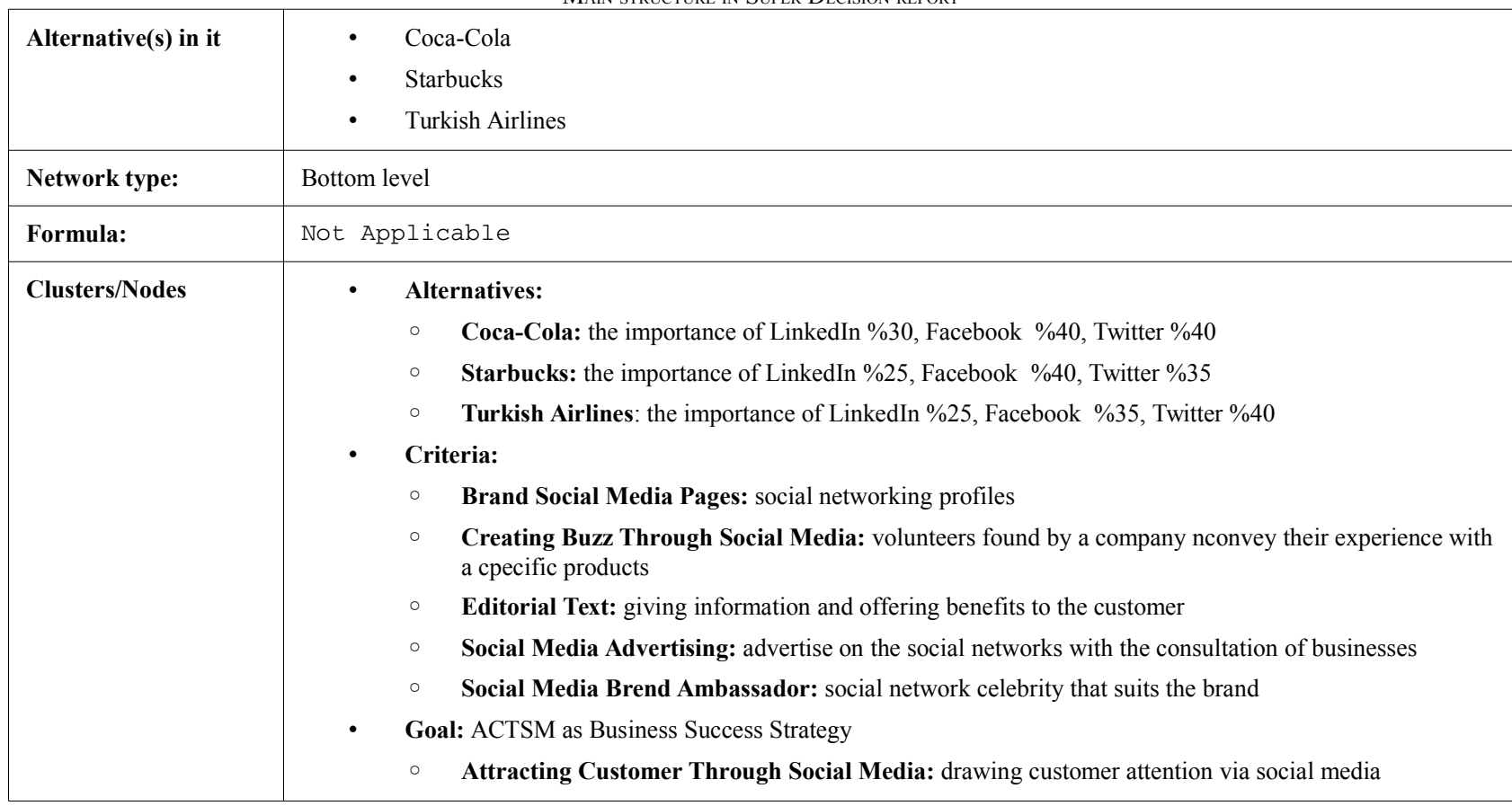


TABLE III

Alternative ranking in Super Decisions Report

\begin{tabular}{||c||c||c|c|c|c||}
\hline Graphic & Alternatives & Total & Normal & Ideal & Ranking \\
\hline \hline & Coca Cola & 0.2170 & 0.4340 & 1.0000 & 1 \\
\hline \hline & Starbucks & 0.0781 & 0.1562 & 0.3600 & 3 \\
\hline \hline & Turkish Airlines & 0.2049 & 0.4097 & 0.9440 & 2 \\
\hline \hline
\end{tabular}

with the costumers in lower costs and greater efficiency than traditional media tools (Kaplan and Haenline, 2010).Recently one of the most important issues of the businesses involved in social media is to measure the success of social media and events. Therefore, to measure the success of social media marketing, and it has become important to determine the measurement criteria to guide the social media marketing, according to information obtained.

The aim of this study was to analyze social media strategies of the global enterprises and raise enterprises awareness by understanding the value of using social media tools in order to differentiate in the global competition. For this purpose, some global company examples are named which are Turkish Airlines, Coca Cola and Starbucks then social media main criteria are determined and show how the methodology of analytic hierarchy process is executed through main criteria that enterprises are able to use.

As a result, in the scope of social media (LinkedIn, Facebook, Twitter), in order to attract the customer, Coca Cola is using social media tool more effective than Turkish Airlines; Turkish Airlines is using social media tool more effective than Starbucks.

\section{REFERENCES}

[1] Barutcu S., Tomas M., (2013) Sürdürülebilir Sosyal Medya Pazarlaması ve Sosyal Medya Pazarlaması Etkinliğinin Ölçümü. IUYD 2013, 4(1), p.6-23.

[2] Coca Cola Company, (2013), Social Media Principles, retrieved from https://www.coca-colacompany.com, Access:04.03.2016

[3] Culnan M. J., McHugh P. J., Zubillaga J.I. (2010). How Large U.S. Companies Can Use Twitter and Other Social Media to Gain Business Value. MIS Quarterly Executive 9(4).

[4] DeLone W. H., McLean E.R. (2014). Measuring e-Commerce Success: Applying the DeLone \& McLeanInformation Systems Success Model. International Journal of Electronic Commerce, 9(1), pp.31-47.

[5] Dhir S., Marinovb M. V., Worsleyb D., (2015). Application of the analytic hierarchy process to identify the most suitable manufacturer of rail vehicles for High Speed 2. Case Studies on Transport Policy, (3), p.431-448

[6] Drury G. (2008). Opinion piece: Social media: Should marketers engage and how can it be done effectively?. Journal of Direct, Data and Digital Marketing Practice, (9), p.274-277.

[7] EticaretMag, E-ticaret Şirketleri İçin Sosyal Medya Kullanım Rehberleri, retrieved from http://eticaretmag.com/e-ticaret-sirketleriicin-sosyal-medya-kullanim-rehberleri/, Access: 04.03.2016

[8] Feng H., Qjian X. (2013). Mining user-contributed photos for personalized product recommendation. Neurocomputing, (129), pp.409-420. Department of Information and Communication Engineering, Xi'an Jiaotong University, Xi'an 710049, China.

[9] Güner, H., (2005), Bulanık AHP ve bir İşletme İçin Tedarikçi Seçimi Problemine Uygulanmasi, Pamukkale University Institute of Science Industrial Engineering Department, p.133

[10] Ho W., (2008), Integrated Analytic Hierarchy Process and its Applications-A literature Review, European Journal of Operational Research, (186), p.211-228
[11] Kahya E., (2016). Analyzing unstructured Facebook social network data through web text mining: A study of online shopping firms in Turkey. Information Development, 32(1), pp.70-80. doi: $10.1177 / 0266666914528523$

[12] Kaplan A.M. ve Hainlein M. (2010). Users of the World, The challanges and Opportunities of Social Media, Business Horizons, 53, 59-68

[13] Kong F., Liu H. (2005). Applying Fuzzy Analytic Hierarchy Process to Evaluate Success Factors of E-Commerce. International Journal of Information and Systems Sciences, 1(3-4), pp.406-412.

[14] Linda S., (2010). Social Commerce - E-Commerce in social Media Context. World Academy of Science, Engineering and Technology International Journal of Social, Behavioral, Educational, Economic, Business and Industrial Engineering, 4(12).

[15] Saaty T. L., (2006). Fundamentals of Decision Making and Priority Theory. RWS Publications 4922 Ellsworth Avenue, Pittsburg, PA 15213, p. 94

[16] Saaty, T. L., Niemira, M.P., (2006), A framework for making a better decision, Research Review, p. 13

[17] Saaty, T.L (2008). Decision Making for Leaders: The Analytic Hierarchy Process for Decisions in Complex World. Pittsburg, Pennsylvania: RWS publications. 8

[18] Supciller A. A., Capraz O., (2011), AHP-TOPSIS Yöntemine Dayalı Tedarikçi Seçimi Uygulaması. Ekonometri ve İstatistik, (13), p.1-22

[19] Tanbeer S.K., Leung C.K., Cameron J.J. (2014). Interactive Mining Of Strong Friends From Social Networks And Its Applications In ECommerce. Journal of Organizational Computing and Electronic Commerce, (24), pp.157-173, doi:10.1080/10919392.2014.896715

[20] Tang L., Liu H., (2010). Community Detection and Mining in Social Media. Synthesis Lectures on Data Mining and Knowledge Discovery. Morgan \& Claypool Publishers, doi:10.2200/ S00298ED1V01Y201009DMK003

[21] Winer R.S. (2009). New Communications Approaches in Marketing: Issues and Research Directions. Journel of İnteractive Marketing, 23, pp.108-117. Marketing Szience Institute, Stern School of Business, New York University, USA.

[22] Zafarani R., Abbasi M.A., Huan L. (2014). Social Media Minging. Cambridge University Press, April 20, 2014. draft version:

\section{APPENDIX}

Some of importance comparison table are as follows.

With respect to Coca-Cola, creating buzz trough social media is moderately more important than brand social media.

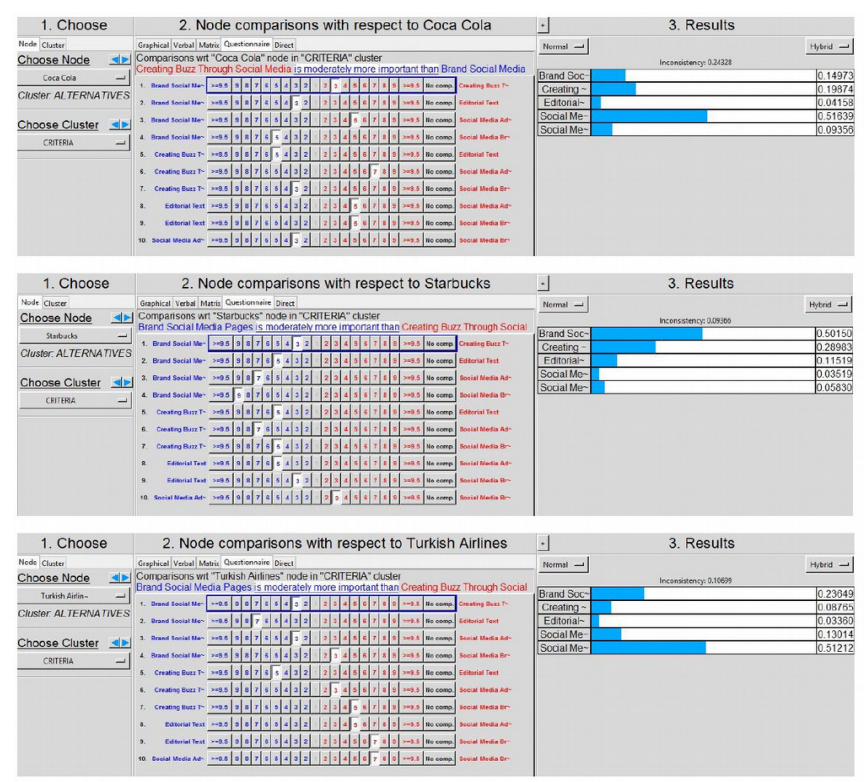

